\title{
Reproductive phenology of the arborescent cactus Eulychnia acida Phil. under three agroecological conditions in the Coquimbo Region, Chile
}

\author{
Angélica Salvatierra ${ }^{1^{*}}$ \\ ${ }^{1}$ Instituto de Investigaciones Agropecuarias, INIA Intihuasi, Colina San Joaquín s/n, La Serena, Chile. \\ "Corresponding author (asalvatierra@inia.cl).
}

Received: 20 November 2019; Accepted: 8 February 2020; doi:10.4067/S0718-58392020000200253

\begin{abstract}
Eulychnia acida Phil. is an arborescent cactus species endemic to Chile, and widespread in the Coquimbo Region, Chile. Wild populations are found on north facing slopes and vary morphologically in fruit shape and color. We conducted a study on reproductive phenology at three locations in the region: Quebrada Honda in the coastal area, Gualliguaica in the Elqui Valley, and La Coipa in the Limarí Valley. A total of 120 stems from 30 selected plants of wild populations were monitored weekly and the phenological stages were evaluated over a season. Through multivariate analysis was determined if climatic factors affected the number of individual and/or reproductive organs observed. The presence of reproductive phenophases is asynchronous, beginning in late autumn with the appearance of flower buds, which bloom mainly in spring and set at the end of the season. Flowering has a unimodal pattern. The variable fruits by stems is strongly correlated $(p<0.05)$ with the relative humidity (negative) and the degree days (positive). Locations show differences in the duration of the phenological events, which appear to be related to plant size and abundance of reproductive structures. Flowering synchrony among individuals is low when compared with other cacti; this means less overlap of the flowering periods among individuals, which could be a strategy to ensure insect visitation and pollination. Longer term studies are necessary to establish how weather conditions, rainfall and temperature influence the generation of flower buds, since production is affected in periods of drought.
\end{abstract}

Key words: Cactus, copao, flowering, flowering synchrony, reproductive stages, rumpa.

\section{INTRODUCTION}

Two genera of columnar cacti, Echinopsis and Eulychnia (Hoffmann and Walter, 2004) are found in the Coquimbo Region $\left(29^{\circ}-32^{\circ} \mathrm{S}\right.$ lat), Chile. Eulychnia is a genus that is also found in Peru and includes six to nine species (Nyffeler et al., 1997), including E. acida Phil. (copao or rumpa), an abundant endemic species found mainly in the Coquimbo Region, Chile (Bustamante, 1996). It is distributed between $29^{\circ} \mathrm{S}$ lat (Incahuasi) and $32^{\circ} \mathrm{S}$ lat (Quilimarí) (Bustamante 1996; Squeo et al., 2001). Taking into consideration the general area of copao distribution, hillsides with slopes greater than $15 \%$, and northern exposure from east to west, the area of the Coquimbo Region is estimated at approximately 430000 ha (Squeo et al., 2001). This species grows on hillsides and preferably on north facing slopes; its edible fruits have nutritional attributes and the characteristics of an isotonic (Masson et al., 2011) and medicinal drink (Jiménez-Aspee et al., 2014; 2015), which exhibit morphological variability of fruit shape, color, and size. It was commonly used as animal feed, to construct live fences, and for some handicrafts. However, with rising tourism and the knowledge of the properties of its fruit, human consumption has increased, especially during summertime when fruits ripen. This generates economic activity for dryland farmers who are near wild populations or rely on live copao fences. 
This species has no major conservation problems (Squeo et al., 2001; Hoffman and Walter, 2004). However, given that part of the wild populations is found in areas near local agricultural activity, especially fruit orchards on slopes, there is risk of impact.

Some studies of Eulychnia have been conducted that deal with distribution and the conservation status (Bustamante, 1996; Belmonte et al., 1998), taxonomy (Leuenberger and Eggli, 2000; Hoffmann and Walter, 2004), morphoanatomical characteristics of stems (Nyffeler et al., 1997), floral orientation (Warren et al., 2017), Tristerix aphyllus infestation (Martínez del Río et al., 1995), pattern of recruitment (Cares et al., 2018) and morphological and genetic characterization (Jana et al., 2017). No phenological information has been reported, which is important since harvesting of fruits has become a fledgling productive activity. Harvesting of the fruits is preceded by reproductive phenological events, which define the production potential of the plant, crossing and pollination mechanisms of plant species (Santos et al., 2008), and natural propagation (Novoa et al., 2005). In addition, continuous monitoring of these biological events can detect alterations due to possible causes of biotic factors such as plant size (Ollerton and Lack, 1998; Bustamante and Búrquez, 2008) or abiotic factors (photoperiod, temperature, and humidity) (Santos et al., 2008; Munguía-Rosas and Sosa, 2010).

The objective of this study was to define and establish the different reproductive stages of E. acida, when they occurred in three wild copao or rumpa populations and, the influence of climatic variables about them, in the Coquimbo Region, Chile.

\section{MATERIALS AND METHODS}

\section{Species population}

Wild copao (Eulychnia acida Phil.) populations were located on north facing slopes; 30 individuals were tagged at the reproductive stage with healthy stems without cactus mistletoe (Tristerix aphyllus) and height of more than $2 \mathrm{~m}$ in which are in reproductive phase (Bustamante and Búrquez, 2008). Individuals were distributed in an area of approximately 1 ha. They were selected when fruits were available at initial tagging (January 2006) and considering the taxonomic description of the species (Hoffmann and Walter, 2004).

Individuals were characterized for plant height and crown perimeter (at approximately $1.2 \mathrm{~m}$ from the ground); number of stems per plant was counted. Four stems were tagged per plant, which were longer than $1 \mathrm{~m}$, oriented in the four cardinal directions, and on the exterior of the plant.

Reproductive phenology follow-up units were established in wild copao populations with a population density between 300 and 500 individuals ha ${ }^{-1}$ found at three locations in the Coquimbo Region, Chile.

\section{Study sites}

Study sites were located in Gualliguaica (3000'01" S; 7048'31" W, $646 \mathrm{~m}$ a.s.l., Province of Elqui), Quebrada Honda

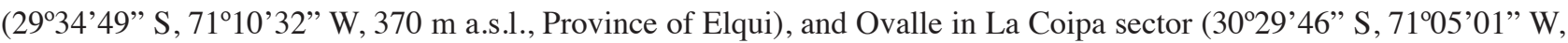
$434 \mathrm{~m}$ a.s.l., Province of Limarí) where there are populations that could be harvested by the locals (Figure 1).

\section{Determination of reproductive phenology}

Data about phenological stages were taken using the criterion of presence or absence of reproductive organs (Novoa et al., 2005) in 120 tagged stems of different individuals distributed in the population. In addition, the weekly increase of each reproductive structure was recorded (Santos et al., 2008; Renzi et al.,2018). Phenological monitoring generated a reproductive phenology map in which eight stages or phenophases were established: 1. Cottony areola, 2. swollen flower bud, 3. bud starts to flower, 4. flowers start to open, 5. full flower, 6. expanded flower, 7. fruit set, and 8. ripe fruits (Figure 2). Weekly evaluations were conducted at each site from January 2006 to February 2007; data were recorded from the flower bud stage (stage 1) to the fruit ripening stage (stage 8). To facilitate data analysis, phenological information was subsequently grouped into three major events: flower bud included stages 1 and 2, flowering included stages $3,4,5$, and 6 , and fruiting was stage 7 . Therefore, the mean number of flower buds, flowers, and fruits on the stems observed on each date was used to determine the peak moments of each stage.

On the basis of this information, dates of occurrence, peak moments, duration of each stage, and productive potential in adult stems were established for each location under study. The degree of overlap of flowering periods between individuals 
Figure 1. Location of study sites, Coquimbo Region, Chile.

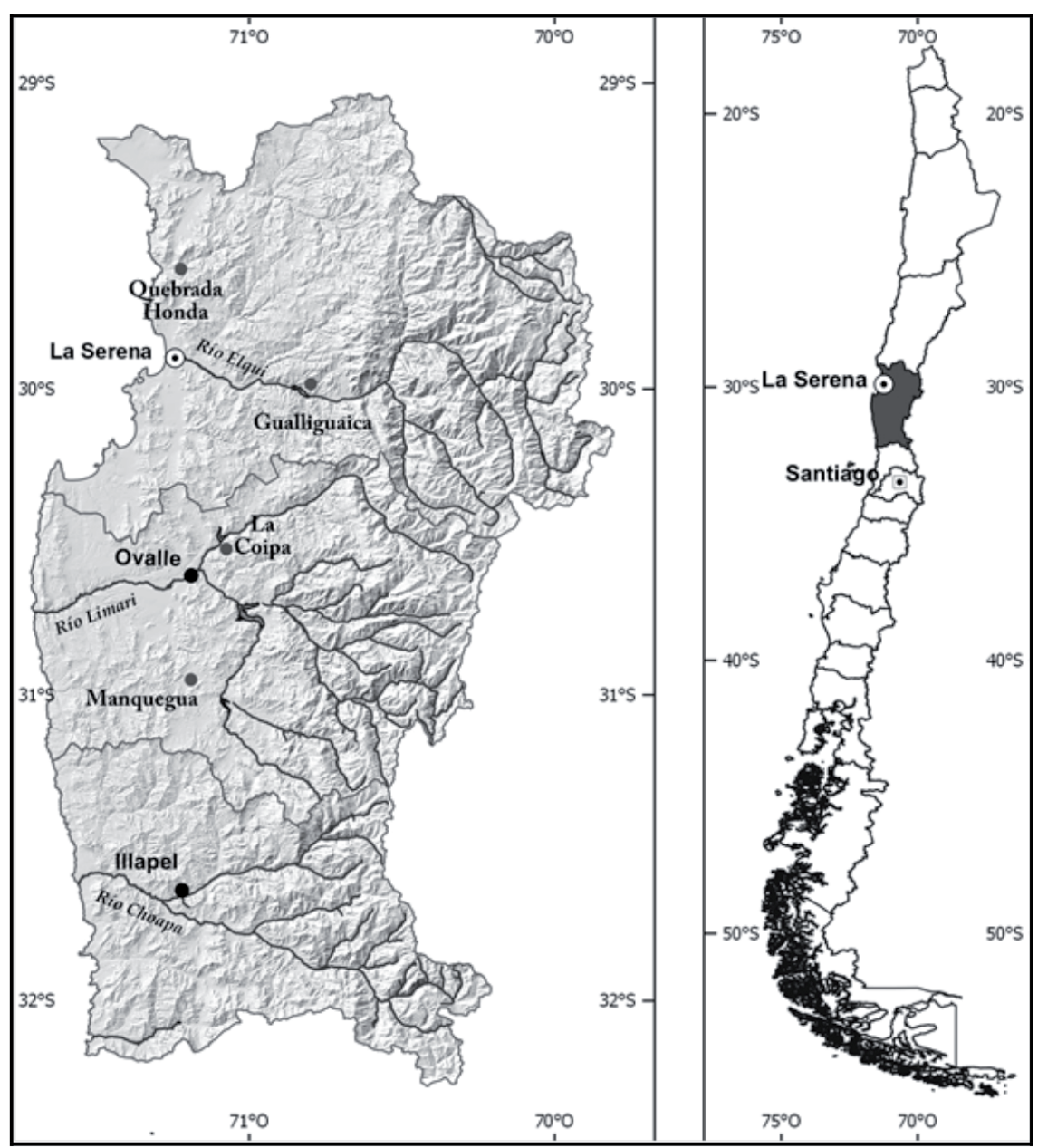

in each studied population was determined by applying the Augspurger flowering synchrony index (Augspurger, 1983) according to the following equation

$$
X i=(1 / n-1)(1 / f i) \sum_{j=1}^{n} e j \neq i
$$

where $e_{i}$ is the number of dates on which plants $\mathrm{i}$ and $\mathrm{j}$ coincide in flowering, $f_{i}$ is the number of dates observed when plant $i$ was flowering, and $n$ is the number of individuals of the census population. In the present study, the Augspurger synchrony index was determined by considering all the events related to flowers (stages 3 to 6) (Figure 2) because the event of open flowers in E. acida is gradual and relatively short (2 to $3 \mathrm{~d}$ ); therefore, weekly monitoring detects a smaller number of opened flowers in stage 6 (Figure 2).

\section{Climatic conditions of study sites}

A temperature and relative humidity logger (HOBO data logger Pro RH/Temp Model H 08-032-08, Onset, Cape Cod, Massachusetts, USA) was installed at each monitoring site. Precipitation was recorded with a pluviometer (HOBO Event logger H07-002-04, Onset). Each variable was recorded every hour during the study period (2006-2007).

The Gualliguaica and La Coipa locations had similar temperatures during the evaluation period; as for relative humidity, Gualliguaica had relatively higher air dryness than in Ovalle in the La Coipa sector. Meanwhile, Quebrada Honda differed especially in temperature and was characterized by high relative humidity. Precipitation that year occurred mainly in autumn and winter months, and it was sporadic and relatively low (Figure 3). 
Figure 2. Phenological stages of Eulychnia acida. A) Stage 1. Cottony areola in the axillary thorns and beginning of floral bud formation. B) Stage 2. The flower bud begins to swell and grows in length and diameter. The thorns tend to drop. C) Stage 3. The flower bud reaches its maximum length and the perianth begins to develop in the apex. D) Stage 4. Tepals begin to appear, which can be white, pink, or red-veined and form the perianth. E) Stage 5 . The flower begins to open and the stamens are visible. F) Stage 6. The flower reaches its maximum opening in which the stamens and pistil are visible. G) Stage 7. A scar is set in the exposed part of the floral structure. The fruit is shaped like a spinning top. H) Stage 8. Fruit at the harvesting stage with shiny skin.
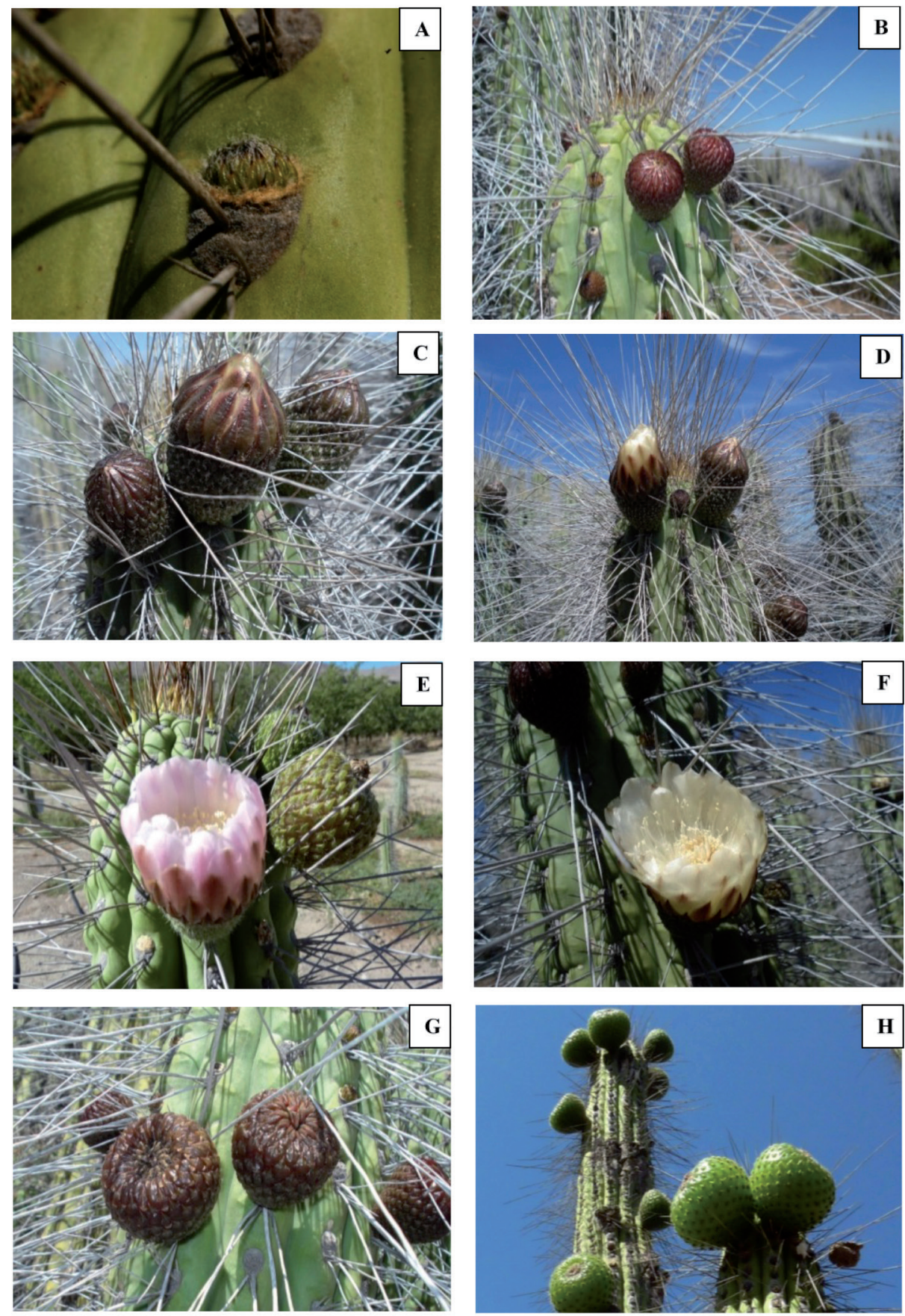
Figure 3. Temperature records (A) every hour and relative humidity (B) at the three locations with phenological monitoring.
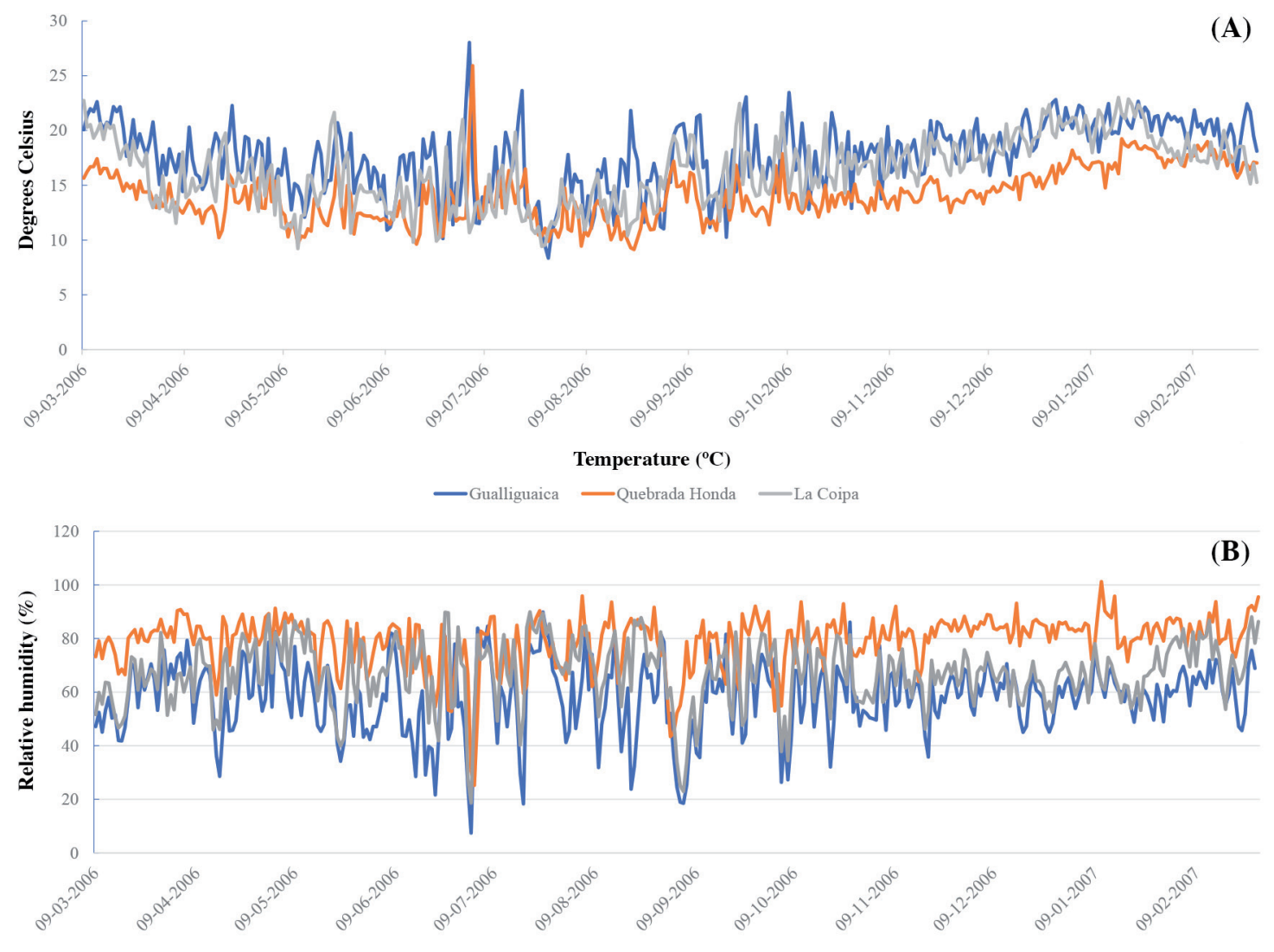

\section{Statistical analysis}

Population characterization was analyzed by descriptive statistics (means and standard deviation); the duration of the phenological periods, number of reproductive structures, and synchrony index were subjected to ANOVA to determine if there were differences between locations. When differences existed, the Student-Newman-Keuls multiple comparison test $(p<0.05)$ was applied. All statistical analyses were performed with the Statgraphics software (Statpoint Technologies, The Plains, Virginia, USA).

To establish whether there is of climatic variables, rainfall, temperature and relative humidity influence on the reproductive phenology in each of the study sites, a multivariate analysis of principal components (PCA) was performed using INFOSTAT/P 1.1 for Windows software (Grupo InfoStat Professional, Facultad de Ciencias Agropecuarias, Universidad Nacional de Córdoba, Córdoba, Argentina). Principal component analysis (PCA) showed that 73\% of the variation in the populations at the three locations can be explained by the first two principal components (PC1 and $\mathrm{PC} 2$ ) with $73.5 \%$ and $26.5 \%$ of the observed variation, respectively.

\section{RESULTS AND DISCUSSION}

Plants selected at the Gualliguaica location exhibited greater height than those from Quebrada Honda and La Coipa. However, individuals from La Coipa were characterized for their high number of branches (stems), which ultimately influenced final plant perimeter (Table 1). Site population density in which the tagged individuals were established varied between locations, and Quebrada Honda had the highest density. 
Table 1. Morphological characteristics of Eulychnia acida individuals of natural populations at three locations in the Coquimbo Region, Chile.

\begin{tabular}{lccc}
\hline & \multicolumn{2}{c}{ Locations } \\
\cline { 2 - 3 } & Quebrada Honda & Gualliguaica & La Coipa \\
\hline Height, m & $2.29 \pm 0.47$ & $3.19 \pm 0.7$ & $2.7 \pm 0.66$ \\
Crown perimeter, m & $4.09 \pm 0.93$ & $4.1 \pm 1.0$ & $4.87 \pm 1.18$ \\
Stems, number per plant & $16.5 \pm 6.54$ & $16.6 \pm 7.05$ & $24.2 \pm 10.1$ \\
Population density, plants ha ${ }^{-1}$ & $510 \pm 101.5$ & $353 \pm 107.8$ & $371 \pm 139.9$ \\
\hline
\end{tabular}

$\mathrm{N}=30$ individuals; $\mathrm{n}=3$ plots of $20 \times 50 \mathrm{~m}$ (mean values \pm standard deviations) in each sector.

\section{Reproductive phenology and climatic conditions}

The stages of Figure 2 can be used as a specific guide to record the events in E. acida. It is worth noting that the reproductive habit of E. acida is to produce a single flower in the areola during the season; this concurs with other cacti (Mauseth and Kiesling, 1997). The flower buds located in the apical part of the stems oriented with northern or northeastern exposure rarely occur in the distal part of the stems or in another geographical exposure. Warren et al. (2017) relate this common habit in several cacti with the efficiency of carbohydrate transport from the tissues that receive more solar radiation toward the reproductive tissues. The reproductive phenology pattern observed in E. acida is similar to those reported for other columnar cacti (Novoa et al., 2005; Bustamante and Búrquez, 2008; Santos et al., 2008; Salomón-Montijo et al., 2016). The flower bud phase was recorded during the whole sampling period ( $9 \mathrm{mo}$ ) between the end of autumn and beginning of summer (May to January), although more intensely toward the end of winter and beginning of spring after to autumn rainfall (Figure 4A). This differs with observations for Neoraimondia arequipensis, columnar cactus of coastal Peru (Novoa et al., 2005) in which the bud phase is year round. Cactus reproductive phenology normally responds to environmental conditions, especially to the presence or absence of rainfall (Petit, 2001; Pimienta-Barrios and del Castillo, 2002; Bustamante and Búrquez, 2005; García-Suárez et al., 2007; Santos et al., 2008, Eggli and Giorgetta, 2017) or to temperature (Rojas-Sandoval and Meléndez-Ackerman, 2011). Eulychnia acida flower buds can be observed from the end of summer and beginning of autumn. However, they remain as such and bear fruit in the next growing season.

Flowering was continuous with a unimodal curve that was slightly extended between the beginning of spring (end of September) and mid-summer (end of January). Overall, there were no marked differences in the flowering pattern between the three locations (Figure 4B), although there were differences for intensity and duration of the main phenological events. Intensity, that is, the number of flowers on a given date (Bustamante and Búrquez, 2008), was higher in Gualliguaica, followed by La Coipa and Quebrada Honda; the latter exhibited a very low occurrence of flowering during the whole sampling period. Maximum flowering (mean of flowers per stem) in La Coipa was recorded in November with 0.28 flowers. By contrast, maximum flowering in Gualliguaica was higher ( 0.56 mean flowers per stem), which was recorded in mid-November, date similar to that observed in Quebrada Honda where it was lower (Figure 4B). The bud in stages 3 to 5 can last less than the frequency of sampling monitoring (weekly); this could explain the high number of flowers recorded at the start point of the La Coipa curve.

Flowering in cacti usually appears during the dry season (Pimienta-Barrios and del Castillo, 2002). Similarly, flowering in E. acida occurs in a period in which temperatures begin to increase and the probability of precipitation is lower. The relative humidity (negative $p<0.05$ ) and degree hours (positive $p<0.05$ ) were highly correlationated with fruit per stem (Figure 5) (Rojas-Sandoval and Meléndez-Ackerman, 2011, Nóbrega et al., 2019).

As for fruiting, it began at the end of October in the Gualliguaica sector, $25 \mathrm{~d}$ after Quebrada Honda and La Coipa (Figura 2C). In the last two locations, initial fruiting was low and gradually increased from mid-October onward. Fruiting continued until the end of January and a smaller number of fruits was quantified compared with the flower buds observed at the three locations. This can be caused by the abortion of flower buds and immature fruits for reasons not determined in the present study.

The reproductive stages occur asynchronously in E. acida, that is, there is an overlap of stages especially in spring. This has also been observed in the flowering of other cacti (Pimienta-Barrios and del Castillo, 2002) and would be an advantage against adverse environmental conditions (Pimienta-Barrios and Nobel, 1995). 
Figure 4. Number of reproductive structures (curves) flower buds (A), flowers (B), and fruits (C) per stem and prior rainfall (mm) (bars) for each sampling date of Eulychnia acida in Gualliguaica, Quebrada Honda, and La Coipa, Coquimbo Region, Chile.
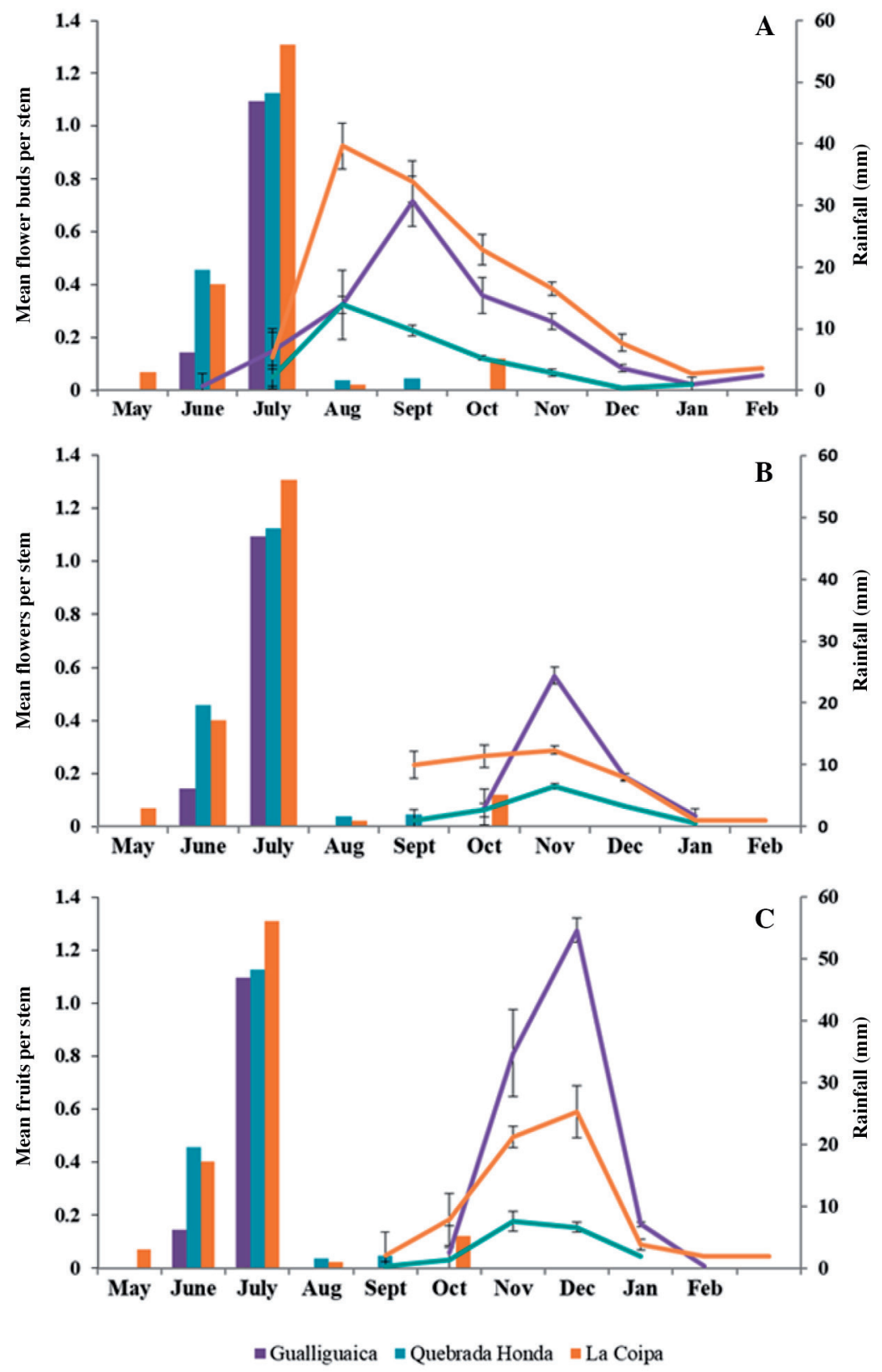

The mean duration of each individual phenophase varied $(p<0.05)$ among the studied populations (Table 2). The difference between locations in the duration of the different stages should be a response to the climatic conditions (Bustamante and Búrquez, 2005; Rojas-Sandoval and Meléndez-Ackerman, 2011) and plant age (Petit, 2001). Principal component analysis allowed separating the populations by evaluated reproductive phenology and environmental conditions, which showed differences between Quebrada Honda, Gualliguaica y La Coipa. La Coipa population was different because of number of reproductive phenological variables, Quebrada Honda for its relative humidity and Gualliguaica for temperature (Figure 5). A pattern such as that observed for the phenophase duration was also recorded for the mean number of each reproductive structure per stem (Table 2). Gualliguaica and La Coipa had higher productivity per stem, which was reflected in the higher mean number of flower buds, flowers, and fruits produced per stem. Higher productivity and earliness observed in La Coipa for flowering can be explained by plant size, as was determined in other columnar cacti (Petit, 2001) in which larger plants produced a higher number of flowers and earlier than the others. 
Figure 5. Biplot of PC1 and PC2 with five standardized phenological variables and four climatic variable sectors for the three populations of Eulychnia acida.

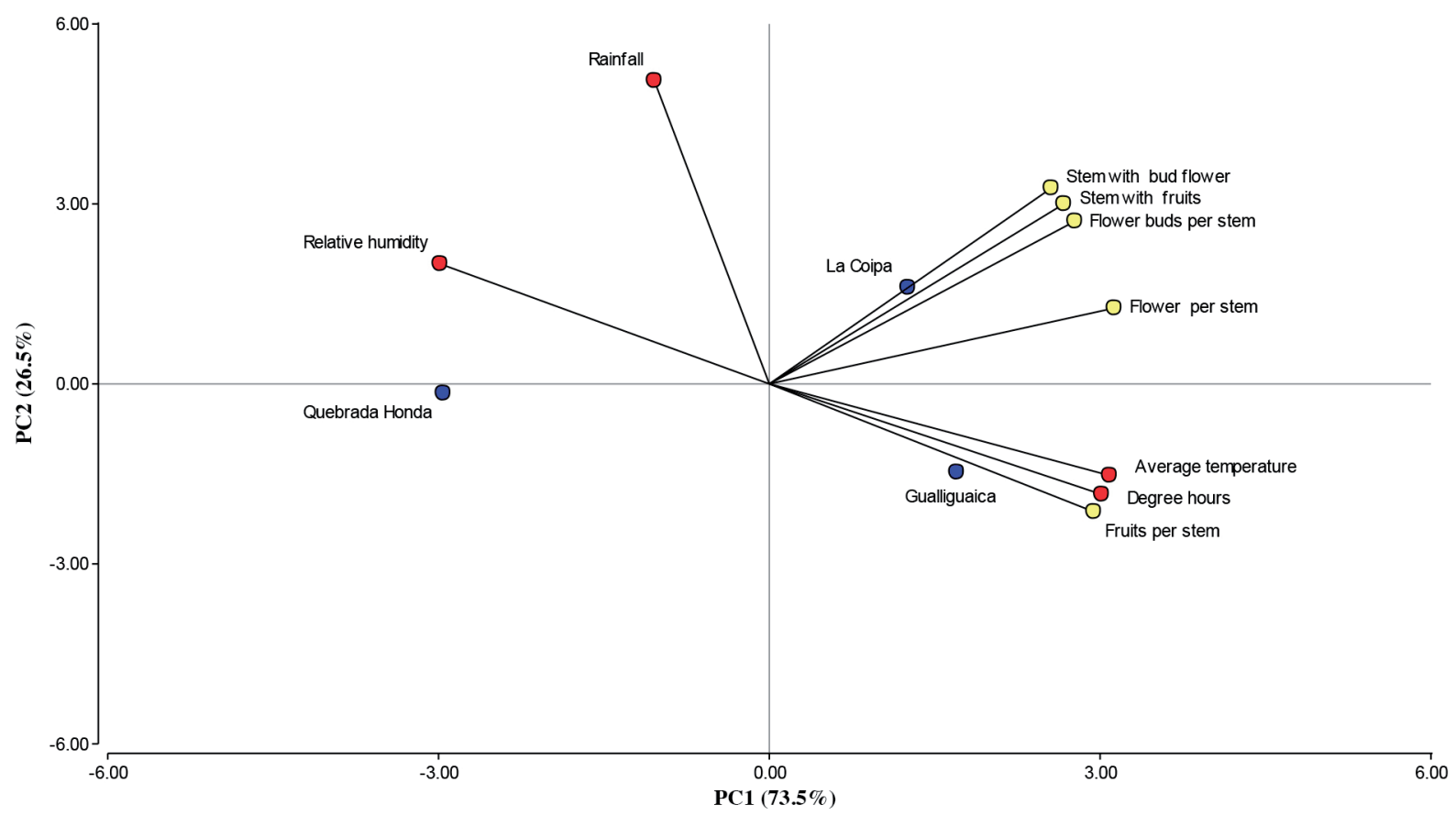

Table 2. Comparison of phenological stages of the columnar cactus Eulychnia acida at three locations in the Coquimbo Region, Chile.

\begin{tabular}{|c|c|c|c|c|c|}
\hline & \multicolumn{3}{|c|}{ Locations } & \multirow[b]{2}{*}{$F$} & \multirow[b]{2}{*}{$P$} \\
\hline & Quebrada Honda & Gualliguaica & La Coipa & & \\
\hline Flower bud stage duration ${ }^{1}, \mathrm{~d}$ & $89.3 \pm 51.5 b$ & $122.7 \pm 50.7 \mathrm{a}$ & $127.4 \pm 30.3 \mathrm{a}$ & 6.32 & 0.002 \\
\hline Flowering stage duration, $\mathrm{d}$ & $33.0 \pm 31.0 \mathrm{~b}$ & $42.8 \pm 26.4 \mathrm{~b}$ & $84.3 \pm 35.0 \mathrm{a}$ & 23.11 & 0.000 \\
\hline Fruiting stage duration, $\mathrm{d}$ & $37.4 \pm 31.2 \mathrm{c}$ & $54.7 \pm 22.3 b$ & $75.5 \pm 20.2 \mathrm{a}$ & 17.45 & 0.000 \\
\hline Flower buds ${ }^{2}$ per stem & $2.1 \pm 1.7 \mathrm{c}$ & $4.4 \pm 3.3 b$ & $10.6 \pm 6.5 \mathrm{a}$ & & \\
\hline (range of values) & $(0-10)$ & $(0-14)$ & $(0-39)$ & 117.37 & 0.000 \\
\hline $\begin{array}{l}\text { Flowers }{ }^{2} \text { per stem } \\
\text { (range of values) }\end{array}$ & $\begin{array}{c}0.9 \pm 1.2 b \\
(0-6)\end{array}$ & $\begin{array}{l}2.5 \pm 2.4 \mathrm{a} \\
(0-14)\end{array}$ & $\begin{array}{l}2.7 \pm 2.2 \mathrm{a} \\
(0-10)\end{array}$ & 28.02 & 0.000 \\
\hline $\begin{array}{l}\text { Fruits }{ }^{2} \text { per stem } \\
\text { (range of values) }\end{array}$ & $\begin{array}{c}1.1 \pm 1.3 \mathrm{~b} \\
(0-7)\end{array}$ & $\begin{array}{c}4.5 \pm 3.2 \mathrm{a} \\
(0-16)\end{array}$ & $\begin{array}{c}4.7 \pm 3.5 \mathrm{a} \\
(0-17)\end{array}$ & 54.6 & 0.000 \\
\hline \multicolumn{6}{|c|}{ Augspurger index } \\
\hline Flowering synchrony & $0.27 \pm 0.12 \mathrm{c}$ & $0.43 \pm 0.13 b$ & $0.49 \pm 0.06 \mathrm{a}$ & 31.5 & 0.000 \\
\hline
\end{tabular}

'Duration of each phenophase is the mean of 30 individuals.

${ }^{2} \mathrm{n}=120$ stems \pm standard deviation.

Different letters in the same row indicate significant differences according to the Student-Newman-Keuls test $(p \leq 0.05)$.

The greater productive potential in La Coipa was not necessarily reflected in a higher number of fruits. This can be associated with pollination problems and/or the presence of Zophodia chilensis (Syn. Sigelgaita chilensis, prickly pear moth) larvae that finally provoke abortion of reproductive stages.

The flowering synchrony of E. acida individuals according to the Augspurger index (Augspurger, 1983) was less than 0.49 at the studied locations (Table 2); this indicates that the degree of flowering overlaps among individuals for the locations and year under study. Flowering synchrony among individuals is associated with a strategy to improve visitation expectations and subsequent entomophilic pollination, thus increasing pollination efficiency (Bustamante and Búrquez, 2005; Eggli and Giorgetta, 2017). 
The extension of the phenophase period is related to the number of reproductive structures that gradually develop in the plant and overlap each other. In fact, La Coipa location exhibits a greater extension of the phenological periods and more reproductive stages.

As for E. acida, the appearance of flower buds was expressed to a greater extent with autumn rainfall between 60 and $80 \mathrm{~mm}$ in the study areas, which occurred 1 to 2 mo before the flower bud peak. However, no correlation was found between presence of flower buds and rains.

The duration of the flowering period, as well as its onset, is related to plant size (Ollerton and Lack, 1998; McIntosh, 2002; Renzi et al., 2018). The duration of the bud appearance, flowering, and fruiting period in La Coipa, which exhibited larger plant size, was considerably longer than in Gualliguaica and Quebrada Honda.

\section{CONCLUSIONS}

There is an 8-mo period from the onset of the Eulychnia acida flower bud after autumn rainfall to flowering; fruit ripening begins in the summer, depending on the climatic conditions of each sector. The different phenological stages are asynchronous, overlapping during all the phenological stages from spring onward. The Augspurger index, indicative of flowering overlap among individuals, was the highest in Gualliguaica at 0.49; however, this value was low compared with other cacti.

The three studied populations expressed phenological stages at a similar date; however, they differ in productive potential that can be associated with plant age and size. The wild populations in La Coipa and Gualliguaica reached higher productivity per stem than in Quebrada Honda. Fruits began to ripen at the start of summer. There was correlation between presence of flower buds and rainfall. The temperature expressed as degree days influences the number of fruits per stem and, the relative humidity correlates negatively with this same phenological variable. Longer term studies are necessary to establish how weather conditions, rainfall and temperature, influence the generation of flower buds, since production is affected in periods of drought.

The proposed scale of phenological stages allowed determining the occurrence of the reproductive stage of this arborescent cactus endemic to Chile, which could be of interest to strengthen conservation and sustainable management strategies for the exploitation of its fruit, especially in those areas near farms such as in the Elqui and Limarí Valleys.

\section{ACKNOWLEDGEMENTS}

Thanks to Lucía Martínez González, who was in charge of collecting field information, Maritza Araya, a student at the Universidad de La Serena, Constanza Jana A. INIA Intihuasi for its collaboration in multivariate statistical analysis and Pedro León INIA La Platina, who participated in the beginning of this research. This study was financed by the Foundation for Agrarian Innovation (Fundación para la Innovación Agraria, FIA).

\section{REFERENCES}

Augspurger, C.K. 1983. Phenology, flowering synchrony, and fruit set of six neotropical shrubs. Biotropica 15:257-267.

Belmonte, E., Faúndez, L., Flores, J., Hoffmann, A., Muñoz, M., y Teillier, S. 1998. Categorías de conservación de las cactáceas nativas de Chile. Boletín del Museo Nacional de Historia Natural 47:69-89.

Bustamante, R.A. 1996. Distribución, estado de conservación y uso de las cactáceas columnares en la Región de Coquimbo. Tesis Escuela Agronomía. Universidad de Chile, Facultad de Ciencias Agrarias y Forestales, Santiago, Chile.

Bustamante, E., y Búrquez, A. 2005. Fenología y biología reproductiva de las cactáceas columnares. Cactáceas y Suculentas Mexicanas 50(3):68-88.

Bustamante, E., and Búrquez, A. 2008. Effects of plant size and weather on the flowering phenology of the organ pipe cactus (Stenocereus thurberi). Annals of Botany 102:119-130.

Cares, R.A., Sáez-Cordovez, C., Valiente-Banuet, A., Medel, R., and Botto-Mahan, C. 2018. Frugivory and seed dispersal in the endemic cactus Eulychnia acida: extending the anachronism hypothesis to the Chilean Mediterranean ecosystem. Revista Chilena de Historia Natural 91:9. https://doi.org/10.1186/s40693-018-0079-4.

Eggli, U., and Giorgetta, M. 2017. Flowering phenology and observations on the pollination biology of South American cacti. 3. Temporally robust sequential "big bang" flowering of two unrelated sympatric globular cacti in northern Argentina. Haseltonia 23:97-109. 
García-Suárez, F., Carreto-Montoya,L., Cárdenas-Navarro, R., Díaz-Pérez,J.C., and López-Gómez, R. 2007.Pitaya (Stenocereus stellatus) fruit growth is associated to wet season in Mexican dry tropic. Фyton 76:19-26.

Hoffmann, J.A., y Walter, H. 2004. Cactáceas en la flora silvestre de Chile. 307 p. 2ª ed. Ediciones Fundación Claudio Gay, Santiago, Chile.

Jana, C., Salvatierra, A., Díaz, D., and Martínez, L. 2017. Morphological and genetic characterization among wild populations of copao (Eulychnia acida Phil.), cactus endemic to Chile. Chilean Journal of Agricultural Research 77:3-14.

Jiménez-Aspee, F., Alberto, M.R., Quispe, C., Soriano, M., Theoduloz, C., Zampini, I.C., et al. 2015. Antiinflammatory activity of copao (Eulychnia acida Phil., Cactaceae) fruits. Plant Foods for Human Nutrition 70(2):135-140. doi:10.1007/s11130-015-0468-7.

Jiménez-Aspee, F., Quispe, C., Soriano, M., Fuentes, J., Hüneke, E., Theoduloz, C., et al. 2014. Antioxidant activity and characterization of constituents in copao fruits (Eulychnia acida Phil., Cactaceae) by HPLC-DAD-MS/MSn. Food Research International 62:286-298

Leuenberger, B.E., and Eggli, U. 2000. The genus Eulychnia (Cactaceae) in Chile: Notes on the taxonomy, types, and other old specimens. Haseltonia 7:63-76.

Martínez del Río, C.M., Hourdequin, A., and Medel, R. 1995. The influence of cactus size and previous infection on bird deposition of mistletoe seeds. Australian Journal of Ecology 20:571-576.

Masson, L., Salvatierra, A., Robert, P., Encina, C., and Camilo, C. 2011. Chemical and nutritional composition of copao fruit (Eulychnia acida Phil.) under three environmental conditions in the Coquimbo Region. Chilean Journal of Agricultural Research 71:521-529.

Mauseth, J., and Kiesling, R. 1997. Comparative anatomy of Neuraimondia reoseiflora and Neocardenasia herzogiana (Cactaceae). Haseltonia 5:37-49.

McIntosh, M. 2002. Flowering phenology and reproductive output in two sister species of Ferocactus (Cactaceae). Plant Ecology 159:1-13.

Munguía-Rosas, M., and Sosa, V.J. 2010. Phenology of Pilosocereus leucocephalus (Cactaceae, tribe Cereeae): a columnar cactus with asynchronous pulsed flowering. Plant Ecology 211:191-201. doi:10.1007/s11258-010-9784-z.

Nóbrega, V., Valiente-Banuet, A., and Cardoso, A. 2019. Reproductive phenology of cacti species in the Brazilian Chaco. Journal of Arid Environments 161:85-93.

Novoa, S., Ceroni, A., y Arellano, C. 2005. Contribución al conocimiento de la fenología del cactus Neoraimondia arequipensisi subs. roseiflora (Wendermann \& Backeberg) Ostoloza (Cactaceae) en el Valle del Río Chillón, Lima Perú. Ecología Aplicada 4(1-2):35-40.

Nyffeler, R., Eggli, U., and Leuenberger, B. 1997. Noteworthy idioblastic sclereids in the stem of Eulychnia (Cactaceae). American Journal of Botany 84(9):1192-1197.

Ollerton, J., and Lack, A.J. 1998. Relationships between flowering phenology, plant size and reproductive success in Lotus corniculatus (Fabaceae). Plant Ecology 139:35-47.

Petit, S. 2001. The reproductive phenology of three sympatric species of columnar cacti on Curacao. Journal of Arid Environments 49:521-531.

Pimienta-Barrios E., and del Castillo, R. 2002. Reproductive biology. p. 75-90. In Park, N. (ed.) Cacti. Biology and uses. University of California Press, Berkeley, California, USA.

Pimienta-Barrios, E., and Nobel, P.S. 1995. Reproductive characteristics of pitayo (Stenocereus queretaroensis) and their relationships with soluble sugars and irrigation. Journal of the American Society for Horticultural Science 120:1082-1086.

Renzi, J., Peachey, W., and Gerst, K. 2018. A decade of flowering phenology of the keystone saguaro cactus (Carnegia gigantea). American Journal of Botany 106(2):199-210.

Rojas-Sandoval, J., and Meléndez-Ackerman, E. 2011. Reproductive phenology of the Caribbean cactus Harrisia portoricensis: rainfall and temperature associations. Botany 89(12):861-871.

Salomón-Montijo, B., Reyes-Olivas, A., y Sánchez-Soto, B.H. 2016. Fenología reproductiva de Stenocereus thurberi (Cactaceae) en una región de transición del norte de Sinaloa, México. Gayana Botánica 73(2):381-390.

Santos, R.B., Silveira, L.F., and Leite, E.B. 2008. Reproductive phenology of Melocactus (Cactaceae) species from Chapada Diamantina, Bahia, Brazil. Revista Brasileira de Botanica 31(2):237-244.

Squeo, F., Arancio, G., y Gutiérrez, J. 2001 . Libro rojo de la flora nativa y de los sitios prioritarios para su conservación: Región de Coquimbo. 372 p. Ediciones de la Universidad de La Serena, La Serena, Chile.

Warren, S.D., Aguilera, L.E., Baggett, L.S., and Zuñiga, M. 2017. Floral orientation in Eulychnia acida, an arborescent cactus of the Atacama Desert, and implications for cacti globally. Ecosphere 8(10):e01937. https://doi.org/10.1002/ecs2.1937. 